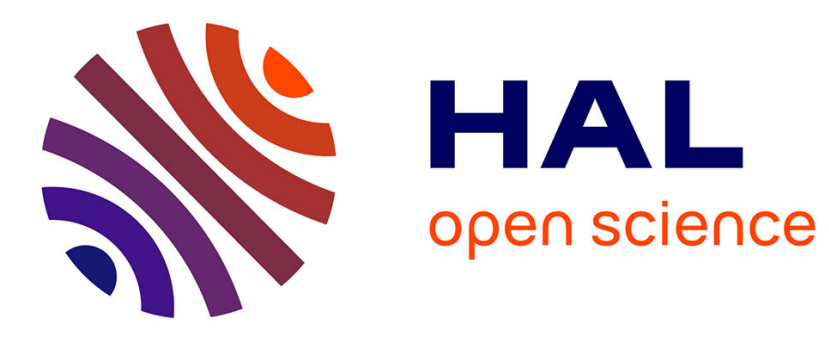

\title{
Creating Art Installation in Virtual Reality. The Stilleben Project
}

Jan K. Argasiński

\section{To cite this version:}

Jan K. Argasiński. Creating Art Installation in Virtual Reality. The Stilleben Project. Esteban Clua; Licinio Roque; Artur Lugmayr; Pauliina Tuomi. 17th International Conference on Entertainment Computing (ICEC), Sep 2018, Poznan, Poland. Springer International Publishing, Lecture Notes in Computer Science, LNCS-11112, pp.301-304, 2018, Entertainment Computing - ICEC 2018. 10.1007/978-3-319-99426-0_34. hal-02128596

\section{HAL Id: hal-02128596 https://hal.inria.fr/hal-02128596}

Submitted on 14 May 2019

HAL is a multi-disciplinary open access archive for the deposit and dissemination of scientific research documents, whether they are published or not. The documents may come from teaching and research institutions in France or abroad, or from public or private research centers.
L'archive ouverte pluridisciplinaire HAL, est destinée au dépôt et à la diffusion de documents scientifiques de niveau recherche, publiés ou non, émanant des établissements d'enseignement et de recherche français ou étrangers, des laboratoires publics ou privés. 


\title{
Creating art installation in Virtual Reality. The Stilleben Project*
}

\author{
Jan K. Argasiński \\ Department of Games Technology \& UBU Lab, \\ Jagiellonian University in Krakow, Poland \\ jan.argasinski@uj.edu.pl
}

\begin{abstract}
The purpose of this paper is to present piece of interactive, Virtual Reality art that was created in UBU Lab at Jagiellonian University in Krakow, Poland. The work is presented in the context of transmedial design. The main challenge and motivation was to create immersive and affective/aesthetically intensive work with engagement of only simple, minimal resources. "The Stilleben" project was based on real-life artworks (graphics, installations, albums) by the artist Jakub Woynarowski and is example of exploratory design created in interdisciplinary, cultural computing laboratory just established at the Jagiellonian University.
\end{abstract}

Keywords: Virtual Reality · interactive art · transmedial narrative

\section{Motivation}

In late 2015 with the support of Polish Ministry of Science and Higher Education there was established the laboratory for creative computing at the Jagiellonian University in Krakow. The idea was to gather group of the interdisciplinary scholars and creators to engage in activities from the borderline of exploratory programming and electronic art.

In his 2016 book [1] Nick Montfort from MIT distinguished the terms "exploration" and "exploitation" in programming. The first style of coding "is not supposed to provide the single solution or 'one true way' to approach computing $(\ldots)$ it's meant, instead, (...) to bring the abilities of the computer to address one's important questions, artistic, cultural, or otherwise".

Among other projects carried out in the lab, such as various literary text generators or demoscene productions, there is one piece dedicated to new paradigm in interactive, transmedial storytelling which is Virtual Reality. The project name is "the Stilleben" and it is being designed by an artist Jakub Woynarowski and developed by computer scientist Jan K. Argasiński.

* "The Stilleben" is part of Creative Computing. The laboratory K/PMI/000260, National Programme for the Development of Humanities grant funded by the Polish Ministry of Science and Higher Education. 


\section{The Stilleben}

The idea behind "the Stilleben" is to transform existing, minimalist, graphic art and installation into similar VR experience.

The guiding principle of Woynarowski's art is always an abstraction in it's board sense. His projects focus on fragile balance between objects being perceived as everyday, ordinary things and their contextual symbolic meaning. His well known work Hikikomori (2007) is specific kind graphic novel/album that creates sort of visual alphabet of common objects that are taken out of everyday meaning by alien intervention of an unidentified, organic substance that breaks into the space of an isolated apartment (see Fig.1).
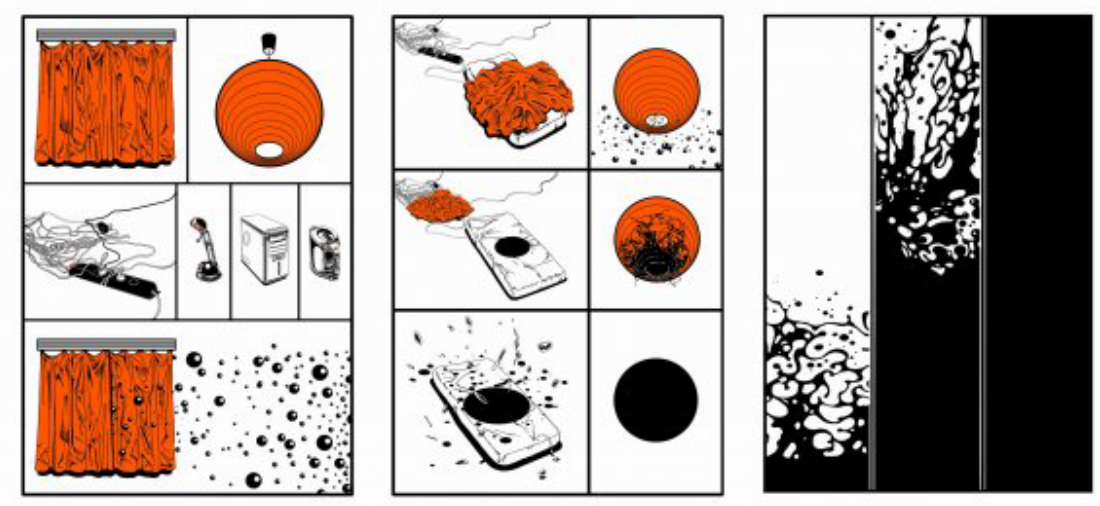

Fig. 1. J. Woynarowski, Hikikomori, excerpts

Hikikomori is Japanese term for "internal confinement" or "isolated entity". This word is used to describe behaviour that consists of withdrawal from public space, social life, seeking isolation. In the album and later in the art installation (2012, see Fig. 2) Woynarowski explores state of self-confinement disrupted by presence of oranic, animated substance which interferes in the hermit's space and seizes it.

"The Stilleben" is continuation and development (in a slightly different direction) of the ideas contained in Hikikomori. This time it referes to the concepts inspired by 17 th century still life paintings (ger. Stilleben) and their depiction of inanimate matter in the state of half-death, being kind of silent life. Still life paintings and their three-dimentional equivalents - cabinets of curiosities, with their allegorical valence and somewhat disturbing conotations are interesting parallels of modern databases or even computers (17th century cabinets were able to perform various tasks, they even contained simple games). 


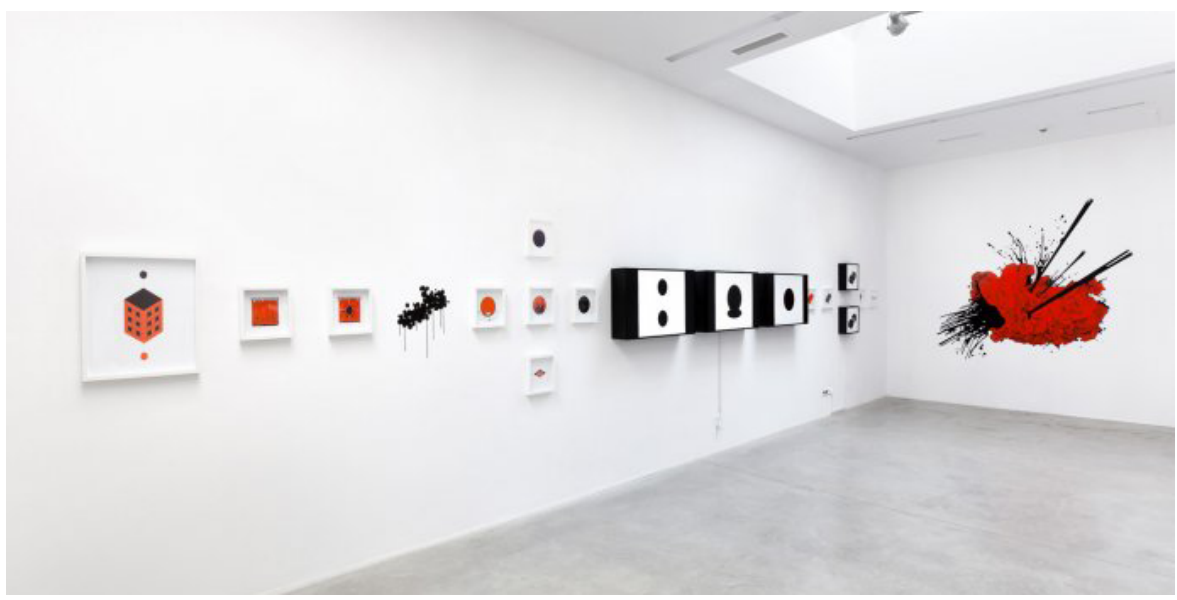

Fig. 2. J. Woynarowski, Hikikomori, art installation in the Museum of Contemporary Art in Krakow (MOCAK), 2012

\section{Designing "the Stilleben"}

As it was said before, Woynarowski - the designer of "the Stilleben" is interested in objects elevated to the level of abstract symbols. In dialtectics of what is outside and what is inside. Synthetic self-confinement versus organic intrusiveness. In "the Stilleben" user finds himself in simple, sterile white cube that later in time becomes luxuriant garden (see Fig. 3). The evolution of "the Stilleben's" single room interior refers to tradition of visual "hexamerons", depicting the stages of Genesis process. The presented story is universal tale of the passage of energy and impermanence of forms, which disintegrate and keep reviving in new shapes.

One of the most important project challenges was to create adequate user experience in Virtual Reality. The planned effect was to simulate a sense of Unheimlich (German word for uncanniness, weirdness). Un-heimlich relates to German Heim - a house; it can be interpreted as un-settle, to not feel like home. Wanted effect was achieved thanks to minimalistic graphic design of the installation and, partially, thanks to the creation of a special space in UBU lab (see next paragraph).

\section{The Implementation}

The Stilleben was implemented by Jan K. Argasiński. The application was created in Unity game engine and VR hardware used was HTC Vive connected to state of the art PC computer. "The Stilleben" was scripted in C\# programming language. VRTK - Virtual Reality Toolkit libraries were used to support the basic SteamVR platform. 

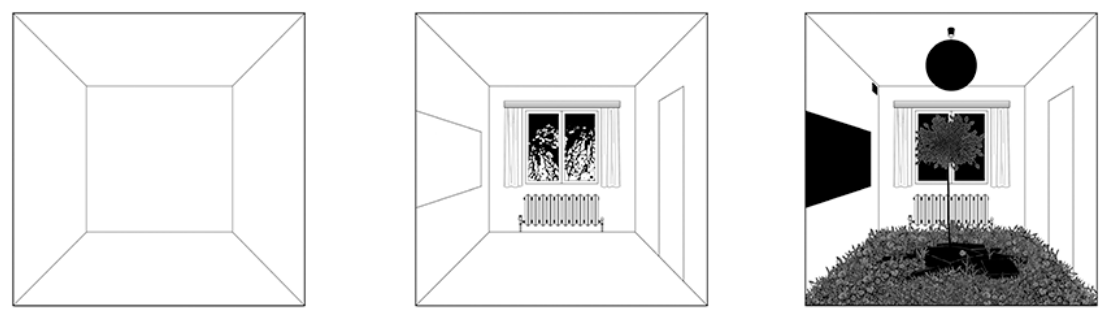

Fig. 3. J. Woynarowski, Stilleben, storyboards for VR application (stages: 1st, 10th and 27th of total 30)

As integral part of the installation dedicated room was built inside UBU lab at the Jagiellonian University in Krakow. The room has exact same dimensions as the VR installation resulting in real confinement of the user. When "spectator" is immersed in VR wearing the headset - he still can move around real space and feel real, non movable objects around him. It allows for deeper influence of the virtual narrative. The key effects occur when the boundary between what is virtual and what is real is broken by the interference of the organic substance. The substance is intangible, untouchable, permeates objects, floats in the air like dust, flows down the walls. Its presence, however is perceived by the user as real. A fully virtual object appears only in the final sequence when the substance explodes with vegetation eventually leading to a complete darkening of the vision.

\section{Conclusion}

The advanced working prototype of "the Stilleben" can be experienced in the UBU Lab at the Faculty of Management and Social Communication of the Jagiellonian University in Krakow, Poland. We believe our work to be interesting piece of art and an informative undertaking in the field of exploratory design. In investigating the boundaries of new medium.

\section{References}

1. Montfort, N.: Exploratory Programming for Arts and Humanities, MIT Press, Cambridge MA, 2016

2. Bolter, J.D.: Writing Space: Computers, Hypertext and the Remediation of Print. Second Edition, Mahwah, 2001

3. Lissitzky, E.: A Suprematist Tale of Two Squares in Six Constructions, London, 2014

4. Grau, O.: Virtual Art. From Illusion to Immersion. MIT Press, Cambridge MA, 2003

5. Kac, E. (Ed.): Signs of Life. Bio Art and Beyond. MIT Press, Cambridge MA, 2007 
6. Kwon, M.: One Place After Another. Site-specific Art and Locational Identity, MIT Press, Cambridge MA , 2002

7. Linowes, J.: Unity Virtual Reality Projects. Pactk Publishing, Birmingham, 2015 


\section{Creating art installation in Virtual Reality The Stilleben Project}

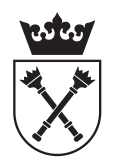

UNIWERSYTET JAGIELLOŃSKI W KRAKOWIE
Ш $\mathrm{日U}$

L H

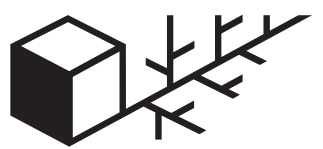

Jan K. Argasinski, Phd

Department of Games Technology \& UBU Lab Jagiellonian University in Krakow, Poland

\section{the Stilleben}

The "Stilleben" is a stationary virtual reality exhibition, simulating sterile, rectangular space, prepared on the premises of UBU laboratory. Exploration of the world presented fror the user is allowed with the virtual reality HMD: HTC Vive, aided by a duet of motion controllers and sensors that determine not only the head movements, but also locate the user, moving freely in three-dimensional space. The shape of the virtual room (realistically reproducing standard elements of interior design) coincides with the actual architectural module. The user's "trip" scenario preserves the unity of time, place and action, and its unchanging scenery frame remains a life-size simulation of a compact, single-person living space.

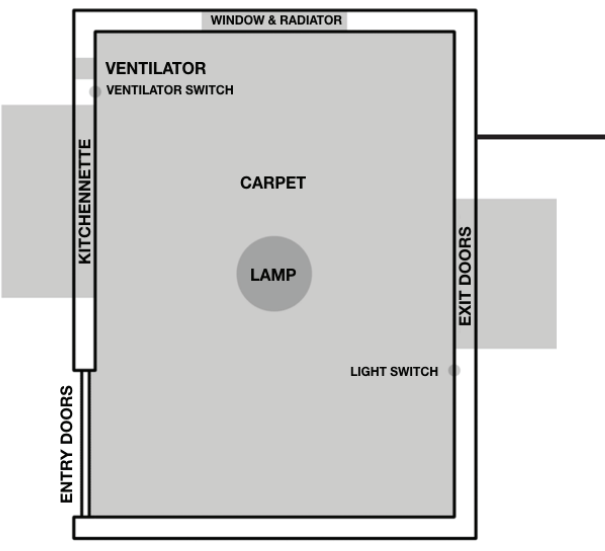

\section{$\square$ REAL ELEMENTS}

WIRTUAL ELEMENTS

The project's focal oscillates around the attempt of the user to master the "foreign element" - an organic structure composed of small black particles, annexing a sterile white room. Each subsequent "task", made by the recipient, initiates the next stage of the exploratory game and involves the activation of the acquired elements of interior architecture. among others windows, ventilation ducts, plumbing, kitchenette, light source, carpet and exit doors. Tips on the next possible interactions made by the user are revealed in the form of visual explications, based on the language of simplified symbol icons. The colors of the stage design remain from the beginning to the end in the gray scale. All "abrupt" changes in the set design - related to the introduction of additional elements and the transition of the user to the new stages of the game - are preceded by a blackout (the effect of "flickering" leading to electricity failure) and re-start of the virtual space lighting.

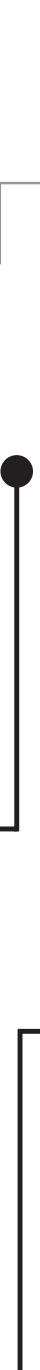
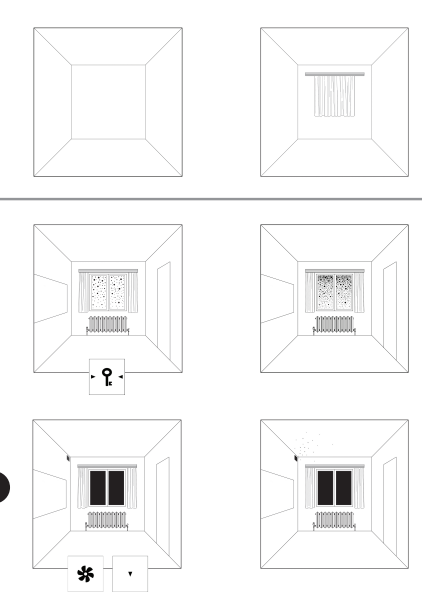

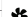

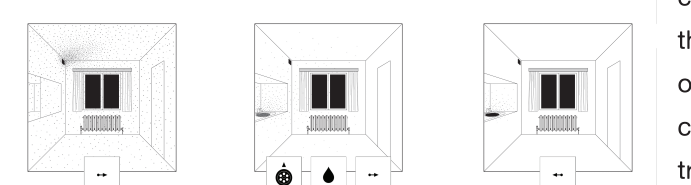

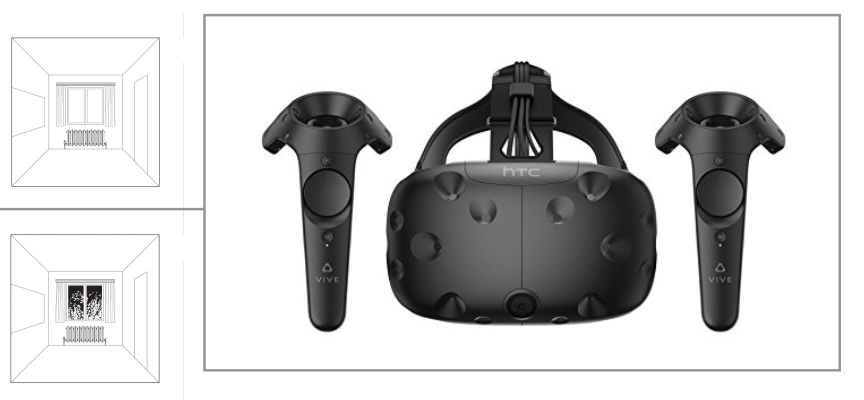

The project was created using Unity game engine and scripted with $\mathrm{C \#}$ programming language.

For the purpose of the project a special VR room was created in the UBU laboratory area. The dimensions of the actual room correspond exactly to the simensions of the virtual room. The physical limitation of space increases the user's immersion in the installation's claustrophobic narrative.

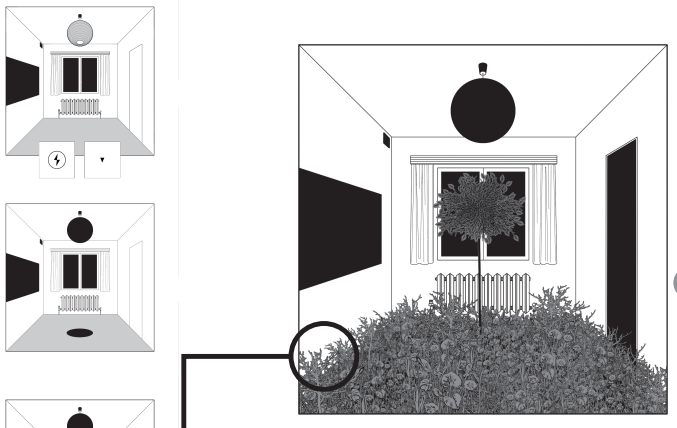

The visual setting and theme of the work refers to and develops the earlier works of Jakub Woynarowski

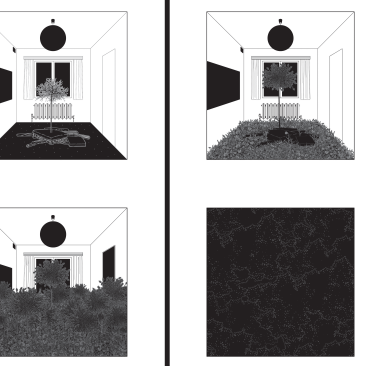
the book "Dead season" and

the exhibition "Hikikomori".
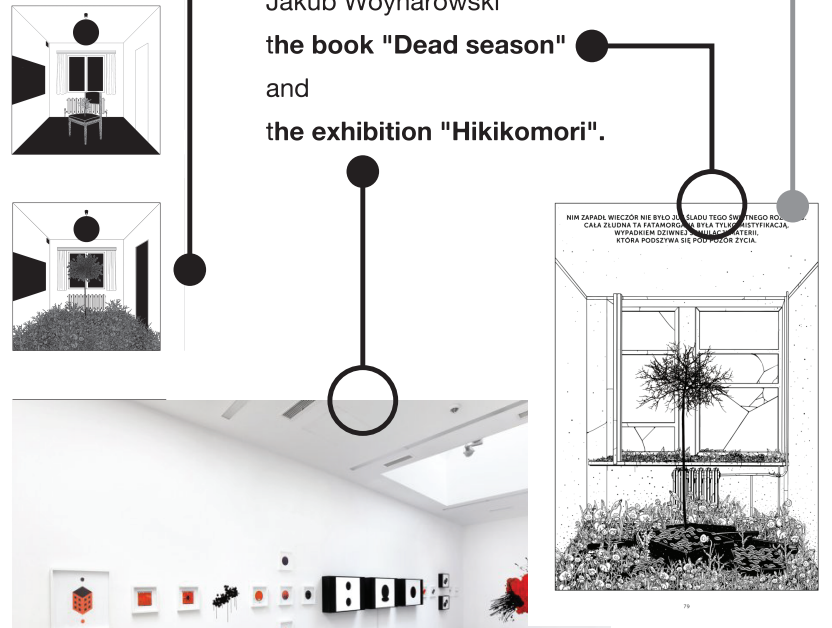